\section{The payment for performance model and its influence on British general practitioners' principles and practice}

\author{
O modelo de pagamento por desempenho e sua \\ influência nos princípios e prática dos médicos \\ generalistas britânicos
}

\author{
El modelo de pago por desempeño y su influencia \\ en los principios y práctica de los médicos \\ generales británicos
}

\author{
1 Durham University, \\ Durham, U.K. \\ Correspondence \\ A. H. Norman \\ Department of Anthroplogy, \\ Durham University. \\ Dawson Building, South \\ Road, Durham, DH1 3LE, \\ U.K. \\ a.h.norman@durham.ac.uk
}

\begin{abstract}
This article explores some effects of the British payment for performance model on general practitioners' principles and practice, which may contribute to issues related to financial incentive modalities and quality of primary healthcare services in low and middle-income countries. Aiming to investigate what general practitioners have to say about the effect of the British payment for performance on their professional ethos we carried out semi-structured interviews with 13 general practitioner educators and leaders working in academic medicine across the UK. The results show a shift towards a more biomedical practice model and fragmented care with nurse practitioners and other health care staff focused more on specific disease conditions. There has also been an increased medicalisation of the patient experience both through labelling and the tendency to prescribe medications rather than non-pharmacological interventions. Thus, the British payment for performance has gradually strengthened a scientific-bureaucratic model of medical practice which has had profound effects on the way family medicine is practiced in the UK.
\end{abstract}

Family Practice; Remuneration; General Practice
Armando Henrique Norman 1

Andrew J. Russell 1

Jane Macnaughton 1

\section{Resumo}

Este artigo explora alguns efeitos do modelo de pagamento por desempenho nos princípios e prática dos médicos generalistas britânicos, podendo contribuir para o debate sobre a relação entre modalidades de incentivos financeiros $e$ qualidade dos serviços na atenção primária à saúde em países de moderada e baixa renda. Objetivando investigar o que os médicos generalistas têm a dizer dos efeitos do pagamento por desempenho britânico sobre seu ethos profissional, conduzimos entrevistas semiestruturadas com 13 médicos generalistas, educadores e líderes no meio acadêmico da medicina no Reino Unido. Os resultados apontam um modelo de prática mais biomédica e fragmentação do cuidado, com enfermeiras e outros profissionais mais focados em doenças específicas. Houve também um aumento da medicalização da vivência dos pacientes, pela rotulação e tendência a prescrever mais medicação e menor uso de intervenções não farmacológicas. Assim, o pagamento por desempenho britânico tem gradualmente fortalecido um modelo científico-burocrático de prática médica que teve efeitos profundos sobre a forma como a medicina de família vem sendo praticada no Reino Unido.

Medicina de Família e Comunidade; Remuneração; Medicina Geral 


\section{Introduction}

The way physicians are paid is paramount for quality in clinical practice, albeit there is no ideal mode of paying doctors. Usually, physicians can be paid by salary, capitation and procedures, which respectively award: time, patient care (workload), and professional performance 1 . As these payment modalities have problems, the trend is to hybridise them in order to minimise their side effects (i.e. capitation with some feefor-service) ${ }^{2}$. In this regard the development of payment for performance schemes by high income countries indicates an effort to enhance the payment modality and improve health service quality 1 . Payment for performance has three main characteristics: set of quality objectives; precise criteria for defining such objectives; and incentives (usually monetary), the overall amount of which depends on the aims to be achieved by each healthcare provider 3 .

Following this international trend, in 2004 general practitioners in the UK entered into a new General Medical Service contract ${ }^{4}$ with the government (containing five key components: held at practice level - not by individual general practitioners; salaried general practitioners with option to continue; practices can opt not to offer 24 hour care; financial incentives to improve information technology for better information retrieval and performance monitoring; and doctors paid according to what they do or produce) which included the Quality and Outcomes Framework (QOF). This uses "pay for performance (...) to foster comprehensive and system-wide improvement in quality of healthcare" 5 (p. 1357). It provides additional payments based on meeting agreed quality targets in clinical care, practice organisation and patient experience 6,7 (Table 1). The QOF is a point-based system with three main types of indicators for obtaining the points 7 (Table 2). Moreover, QOF represents the biggest change in general practitioners contracts since 19668 and is considered the boldest such initiative in the world 5 . In 2004, each QOF point earned a practice about $£ 75$ sterling, evolving to $£ 124.60(2005 / 6)$ and reaching $£ 130.00(2011 / 12) 6$, representing a $20 \%$ increase in general practitioners' salaries 9 and costing the National Health Service (NHS) in excess of $£ 1$ billion 5 . In the first year, general practitioners achieved 959 (91\%) of the available points, above the expected 750 set by policy makers, which meant 'the trust had to find an extra £200m' to cover the difference ${ }^{10}$. Despite the costs, the Health Minister Lord Warner saw it as a "success" and "the world leading intelligence on chronic diseases" 10.
The idea of measuring health service quality originated in the USA in the 1960s with Avedis Donabedian 11. As he saw it, "the criteria of quality are nothing more than value judgments' and definitions of quality " $a$ reflection of values and goals current in the medical care system and in the larger society of which it is a part" 12 (p. 692). "Medical care" changed dramatically during the subsequent half century, and "larger society" has moved towards greater accountability and consumerism. These shifts have led to increased pressure both to define quality in health care and to measure some of its aspects ${ }^{13}$. In the UK quality has tended to be defined by measurable components reflecting the "Whitehall vocabulary of three 'E's': 'efficacy, effectiveness, efficiency"' 14 (p. 59). However, Donabedian's list included four other, less often championed elements: optimality, acceptability, legitimacy and equity. For example, acceptability refers to "wishes, desires and expectation of patients and their families" 11 ( $\mathrm{p}$. 162). This aspect is cursorily taken up by the QOF.

Two major precursors of QOF were the introduction of audit and managerial culture 15,16 and the development of a scientific-bureaucratic medical system 17,18 predicated on evidencebased medical principles 19,20. These presuppose that quality can be measured, and that primary care needs to be more "scientifically" based, while variability in care risks becoming a sign of malpractice. The control and standardisation they engender, under the rhetorical guise of efficiency and accountability, imposes considerable strictures on general practitioners' autonomy 21 .

Critics argue that the narrowness and specificity of QOF's clinical targets (Table 1) risks overmedicalising patients, particularly those with chronic conditions who are unlikely to make rapid lifestyle changes ${ }^{9}$. There is a possibility of excluding patients who threaten the achievement of QOF targets, such as those experiencing treatment side-effects, who fail to attend after three appointment invitations, or who participate in "informed dissent" 22. The attributes of a quality indicator, what makes an area or an indicator "QOF-able' 23, can also be problematic. The focus on "measurable" attributes excludes many other important aspects of healthcare quality. Patient experience, for example, accounts for very few points compared to the $70 \%$ that are linked to the achievement of clinical targets, and the literature provides few examples of positive patient experiences with the General Medical Service contract 24 . Moreover, holism is reframed as "overall achievement in the organisational, patient experience and additional services domains" 23 (p. 105) and is worth just 30/1000 points. The QOF then represents a biomedical model of 
Table 1

Calculation of points for quality framework payments 7 .

\begin{tabular}{|c|c|c|}
\hline $\begin{array}{l}\text { Components of total } \\
\text { points score }\end{array}$ & Points & Way in which points are calculated \\
\hline Clinical indicators & 655 & $\begin{array}{l}\text { Achieving pre-set standards in management of: } \\
\text { - Smoking } \\
\text { - Coronary heart disease } \\
\text { - Heart failure } \\
\text { - Atrial fibrillation } \\
\text { - Stroke and transitory ischemic attack } \\
\text { - Hypertension } \\
\text { - Hypothyroidism } \\
\text { - Diabetes (Hb-1c) } \\
\text { - Chronic kidney disease } \\
\text { - Dementia } \\
\text { - Learning difficulty } \\
\text { - Depression (PHQ-9) } \\
\text { - Mental health } \\
\text { - Chronic obstructive pulmonary disease } \\
\text { - Asthma } \\
\text { - Epilepsy } \\
\text { - Cancer } \\
\text { - Obesity } \\
\text { - Palliative care }\end{array}$ \\
\hline Organizational & 181 & $\begin{array}{l}\text { Achieving pre-set standards in: } \\
\text { - Records and information about patients } \\
\text { - Information for patients } \\
\text { - Education and training } \\
\text { - Medicines management } \\
\text { - Practice management }\end{array}$ \\
\hline Additional services & 36 & $\begin{array}{l}\text { Achieving pre-set standards in: } \\
\text { - Cervical screening } \\
\text { - Child health surveillance } \\
\text { - Maternity services } \\
\text { - Contraceptive services }\end{array}$ \\
\hline Patient experience & 108 & $\begin{array}{l}\text { Achieving pre-set standards in: } \\
\text { - Patient survey } \\
\text { - Consultation length }\end{array}$ \\
\hline Holistic care & 20 & $\begin{array}{l}\text { Reflects range of achievement across clinical indicators - calculated by ranking } \\
\text { clinical indicators in terms of proportion of points gained (1-10). Proportion of the } \\
\text { points gained by the third lowest indicator (i.e. indicator ranked } 7 \text { ) is the proportion } \\
\text { of the holistic care points obtained }\end{array}$ \\
\hline Total possible & 1,000 & \\
\hline
\end{tabular}

quality, implemented through standardised clinical guidelines and payment for conformity ${ }^{9}$.

After initial resistance, by 2001 the British Medical Association (BMA) was an enthusiastic partner in negotiations concerning a "remuneration package" based on quality measurement 13 . The contract has benefitted general practitioners both financially and in terms of workload 
Table 2

Types of indicators 7 .

\begin{tabular}{|c|c|c|}
\hline $\begin{array}{l}\text { Types of } \\
\text { indicators }\end{array}$ & Explanation & Example \\
\hline $\begin{array}{l}\text { Yes/No } \\
\text { indicators }\end{array}$ & $\begin{array}{l}\text { All points are allocated if the result is } \\
\text { positive and none if it is negative. }\end{array}$ & $\begin{array}{l}\text { The Information Indicator } 3 \text { requires practices to have arrangements for patients to } \\
\text { speak to general practitioners and nurses on the telephone during the working day. } \\
\text { The practice must have a written policy on telephone availability and be able to } \\
\text { demonstrate the arrangements if required. }\end{array}$ \\
\hline $\begin{array}{l}\text { Range of } \\
\text { attainment }\end{array}$ & $\begin{array}{l}\text { For most of the clinical indicators, it is not } \\
\text { possible to attain } 100 \% \text { results, even if } \\
\text { allowed exceptions are applied, so a range } \\
\text { of satisfactory attainment is specified, which } \\
\text { varies from } 40 \% \text { to } 90 \% \text {. }\end{array}$ & $\begin{array}{l}\text { The Diabetes Indicator } 5 \text { asks practices to report the percentage of their patients } \\
\text { with diabetes mellitus that have a record of } \mathrm{HbA} 1 \mathrm{c} \text { or equivalent in the previous } 15 \\
\text { months. Three points are available with payment stages of } 40-90 \% \text {. If } 65 \% \text { of the } \\
\text { practice patients do have a record of } \mathrm{HbA} 1 \mathrm{c} \text { within the previous } 15 \text { months, then the } \\
\text { practice will receive } 25 / 50 \text { (i.e. half) of the available points. }\end{array}$ \\
\hline $\begin{array}{l}\text { Minimum } \\
\text { standard } \\
\text { indicators }\end{array}$ & $\begin{array}{l}\text { All points are awarded if the criterion is met } \\
\text { in more than a certain percentage of cases. }\end{array}$ & $\begin{array}{l}\text { The Records Indicator } 18 \text {, worth } 8 \text { points, requires that a practice has up to date } \\
\text { clinical summaries for at least } 80 \% \text { of patient records. }\end{array}$ \\
\hline
\end{tabular}

management, considerations that help explain the BMA's change in position 4 .

This study examines how a selection of general practitioners experience the British payment for performance and what they think about its consequences for their professional ethos, which may help rethink the perspective of implementing financial incentives as a means of improving quality in primary care.

\section{Methods}

It is common in socio-science research and qualitative methods to seek for "key informants" as they may better elaborate and express the views of the social group they belong to. As privileged informants they can act as opinion formers and relevant actors in building the collective stance. Therefore, the selection criteria were that interviewees, in addition to working as part-time general practitioners in primary care, should have some link with medical education, as tutors, teachers or researchers. Thus, the selected general practitioners represent opinion formers and intellectual leaders in family medicine, who can have an influence on future doctors' training and career choices. Interviews were performed with general practitioners working in collaboration with five different institutions within the UK. An initial sample, derived from invitations extended to a network of clinical tutors working at a northern University (the research site), was subsequently expanded, through a "snowball sampling”, to include eight general practitioners from three other UK universities (Cambridge, Manchester, and Edinburgh) and at the London Deanery (responsible for general practitioners Continuing Medical Education). A total of 13 general practitioners representing a range of practice demographics were interviewed (Table 3). Semi-structured interviews using a topic guide, developed by the principal researcher in consultation with his academic colleagues, were conducted at the participant's preferred site between June 30th and August 26th, 2011. They ranged in length from 31:59 to $66: 41$ minutes. Interviews were recorded and transcribed with the subject's consent. Thematic analysis was conducted using the constant comparison method, which is summarised in Table 4. Four key themes (holism, doctor-patient relationship, continuity of care, and quaternary prevention) were framed by the researchers as they address general practitioners' core values. This research was approved by the Research Ethics and Data Protection Committee of the Department of Anthropology of Durham University.

\section{Results}

\section{Holism}

The Royal College of General Practitioners portrays holism as "caring for the whole person in the context of the person's values, their family beliefs, their family system, and their culture in the larger community"; with "emphasis on a more participatory relationship between doctor and patient" 25 
Table 3

Research participants' profile.

\begin{tabular}{|c|c|c|c|c|c|}
\hline $\begin{array}{l}\text { Number of the general } \\
\text { practitioner }\end{array}$ & Sex & $\begin{array}{c}\text { Years of working as general } \\
\text { practitioner }\end{array}$ & $\begin{array}{l}\text { Type of } \\
\text { contract }\end{array}$ & Medical educational activity & UK regions \\
\hline 1 & Male & $>10$ & Partner & Tutor & Northeast, England \\
\hline 2 & Male & $>10$ & Partner & Researcher & East Anglia, England \\
\hline 3 & Male & $>10$ & Partner & Continue medical education & Southeast, England \\
\hline 4 & Male & $>10$ & Salaried & Continue medical education & Southeast, England \\
\hline 5 & Male & $>10$ & Salaried & Teacher & Northeast, England \\
\hline 6 & Female & $>10$ & Salaried & Researcher & Northwest, England \\
\hline 7 & Female & $<10$ & Partner & Tutor & Northeast, England \\
\hline 8 & Male & $<10$ & Partner & Tutor & Northeast, England \\
\hline 9 & Female & $>10$ & Partner & Tutor; teacher & Northeast, England \\
\hline 10 & Male & $>10$ & Salaried & Researcher; teacher & Scotland \\
\hline 11 & Female & $>10$ & Salaried & Tutor & Scotland \\
\hline 12 & Female & $<10$ & Salaried & Tutor; teacher & Scotland \\
\hline 13 & Male & $>10$ & Partner & Researcher & Scotland \\
\hline
\end{tabular}

Partners: general practitioners that are self-employed, running small businesses or practices.

Research methodological design 4.

\begin{tabular}{|c|c|c|}
\hline Research steps & Definition & Explanation \\
\hline Participant selection & Snowball sampling & $\begin{array}{l}\text { This strategy was developed and has subsequently been utilised by researchers as } \\
\text { a solution to researching "hard-to-reach" participants, which is the case of general } \\
\text { practitioners in Britain. It consists of 'identifying a few potential cases of interest, } \\
\text { verifying their interest, eligibility, as well as for accessing potential further cases via the } \\
\text { initial participant's social or professional contacts'. }\end{array}$ \\
\hline Interviews & Semi-structured & $\begin{array}{l}\text { Topic guide providing broad prompts to explore key issues derived from the literature } \\
\text { and researchers' own experience, focusing exclusively in general practitioners' principles } \\
\text { and practice. }\end{array}$ \\
\hline Analytical method & Constant comparison & $\begin{array}{l}\text { This technique basically involves iterative data collection and analysis divided into three } \\
\text { phases. }\end{array}$ \\
\hline Phase 1 & Data reduction & $\begin{array}{l}\text { The topics of interest are selected and extracted from the raw data (i.e. the interview } \\
\text { transcript is "fragmented" and labelled). }\end{array}$ \\
\hline Phase 2 & Data display & $\begin{array}{l}\text { The organisation of the "reduced data" in such a way that it enables a clearer } \\
\text { understanding of it. As our sample was small it did not require any sophisticated } \\
\text { "cognitive devices" to compare and to look for relationships and connections within the } \\
\text { data. }\end{array}$ \\
\hline Phase 3 & Conclusion drawing/verification & $\begin{array}{l}\text { This is a process of interpretation via the identification of patterns and anomalies which } \\
\text { is re-interpreted, modified and even discarded to draw possible conclusions. }\end{array}$ \\
\hline Result presentation & Narrative based approach & $\begin{array}{l}\text { The selected themes were complemented by maintaining a broad "narrative" of each } \\
\text { participant's or case's account. }\end{array}$ \\
\hline
\end{tabular}

(p. 15). The advent of QOF appears to have altered this approach somewhat:

"Holistic approach means you don't push the patients too far... [They] could be taking 30 tablets if you are trying to hit every QOF standard for that patient, so, you have to be holistic and say:

- 'I will compromise... the blood pressure it's not perfect, but I brought it down by ten points, I'm 
happy with that...their diabetes it's not perfect, but we've brought down the Hb-1c a little bit, I'm happy with that; the COPD is not perfect, but... the most important thing here is cholesterol and the fact that there's an atrial fibrillation, so we must make sure that the anticoagulation... the cholesterol levels are perfect, that's my top priority and the others I will play with'... This new definition of holistic care... is, watching all the things [that] are happening in the patients and balancing things. But that is different from the holistic approach from the 1970s'" (general practitioner 5/salaried).

This extract distinguishes between the holism of the 1970s and that of QOF. The former was championed to legitimise general practitioners' practice, differentiating it from the more biomedical approaches of hospital doctors by offering a critique of the biomedical model and its reductionist/mechanistic view of human beings 26 . Holistic care was "patient-centred" and concerned with the patient's total experience of illness' 4 . The QOF definition of holism refers to managing patients with multiple conditions within the organisational and service domains available. Centred on disease management, it says nothing about tailoring treatment to the patients' inner universe, or their social environment.

In talking about the influence of QOF on holistic practice, one general practitioner stated: "I don't think it's made it any easier... the temptation's that once work's been 'salami sliced' into lots of different activities to which there's money attached, that's inevitably a driver" (general practitioner 4/salaried).

Another general practitioner, who sees himself as having a holistic approach, said: "I can foresee a time when doctors will be firmly focused on technology, on QOF, on technical work and will either not be interested in or lose this ability to be a holistic doctor. It's a bit of a threat; I'm not quite sure how much of it existed, anyway" (general practitioner 3/partner).

What seems to be occurring is a gradual transformation in general practitioners' cultural environment from one of pluralism - seen as a hallmark of general practitioners' generalism, versatility and good practice - to one in which standardised or one-way practice is seen as "good" medicine. The QOF has given renewed vigour to the biomedical paradigm, making it the "new" paradigm and reducing the scope for a holistic approach.

\section{Doctor-patient relationship}

For McWhinney 27 (p. 433), the nature of the doctor-patient relationship defines general practice: "general practitioners tend to think in terms of individual patients rather than generalised $a b$ stractions", i.e. Mr or Mrs ' $\mathrm{X}$ ' rather than a disease case. However, QOF is diverting doctors' attention towards the more abstract, scientific realm, that of probabilistic reasoning, centred on population-based research findings rather than the individual patient.

"Is it patient-centred? No, it's not patient-centred at all, 'cause it is population-centred. I think it's there for the good of the patient, predominant$l y$, but... [it is] population-centred rather than patient-centred" (general practitioner 1/partner).

The epidemiological "hierarchy of evidence" embedded in the evidence-based medicine model has no subjective dimension concerning the patient experience and hence providing patient-centred care is problematic 28 .

The intrusion of computers and their new software packages is the key point in the following extract. The latter generate prompts to "help" doctors and nurses collect their "points". In doing so, the consultation becomes even less patientcentred:

"The need to measure things... comes in the way as soon as you switch your computer on. The patient may come in and say 'my foot is hurting'... but you notice the screen and say 'blood pressure check due, blood sugar check due, cholesterol check due'... Your computer is warning you that you're not up-to-date with your requirements for that patient. Unless you have an exceptionally good system which says 'you go and see the nurse', you end up doing blood pressure, cholesterol and then you'll look at the foot. It's inscribing too much in [our minds]... we're losing the ability to balance things" (general practitioner 5/salaried).

General practitioners trained under QOF scheme did not feel it had changed their consultation behaviour: "I don't think it's changed the process of my consultations or practice. I think the way I deal with...patients is still very much the same as I would do as a trainee in terms of the relationship that I have with them. I think... it's organised patient care better from an administration point of view...um... and perhaps even tightened up and improved care" (general practitioner 7/partner).

For other general practitioner, QOF has become so embedded in their lives as an automatic part of interacting with patients:

“For me it's getting in the way, but.. .it's like a reflex, like an instinct now... You just can't change it anymore, because you have to collect QOF You work as a group practice, if you don't do your bit... your partners are not very happy with you... it does earn your income" (general practitioner 3/ partner). 
"If you weren't recording that particular information for QOF, you'd get a yellow box come up saying do this, do that... the eye was inevitably taken to that when you're looking at the patient... I know it's difficult to ignore from the start, but if you did ignore it you'd have a financial penalty" (general practitioner 4/salaried).

Losing money or being a low-score practice is unacceptable. However, pressure to meet QOF requirements changes during the year: "It works to timescales... so everything has to be done by the $31^{\text {st }}$ of March... If it's a measure of quality then your quality goes down when you take a deep sigh of relief in April and May and there's a frantic.. rush of activity... at the end of the financial year, because it's a huge proportion of what we're paid, so it predominates...It has become a tick box, you know, a check list - 'get it done, ignore the patient and what they've come for, and get it done before the 31'st of March' exercise" (general practitioner $9 /$ partner).

These extracts show how the managerial environment has commoditised the doctor-patient relationship, because of the "conceptual currency" embedded in the payment for performance scheme. This "conceptual commodification" aims "to establish a classification system into which unique cases can be grouped in order to provide a definition of medical output or workload" 26 (p. 190-1) This is only possible by reducing the uncertainty inherent in individual cases and pooling them with population-based standardised categories. In this regard, the biomedical model and evidence-based medicine provide an ideal framework for standardised healthcare, while at the same time reducing doctors' professional autonomy and self-governance 26 .

\section{Personal continuity of care}

"Personal continuity of care is an essential attribute of general practice enabling us to deliver care that is both individual and cost effective" 29 (p. 1873) as well as having the potential to increase patients' satisfaction nearly sevenfold 30 . Discontinuity increases levels of uncertainty on both sides, prompting general practitioners to jettison 'wait and see' approaches 29 . This increases the likelihood of false positive tests (and hence iatrogenesis) and reduces the prospects for complaints to resolve spontaneously 31 . Following a patient's individual trajectory means that medical information and personal values can be cross-referenced with knowledge about family and community.

Under the General Medical Service contract, however, continuity of care has declined. This may have been an "unintended and perverse effect" of QOF since "access to any doctor in the practice within 48 hours was linked to incentives, but access to a particular doctor was not" 32 (p. 376). It has become increasingly difficult for patients to see "their" own doctor, as most patients are now registered with practices rather than with individual general practitioners 24 . The increasing numbers of salaried and part-time doctors, and the difficulties some younger doctors find in fulfilling the general practitioner role, were also identified as having negatively influenced continuity of care.

The loss of long-term relational and personal bonds in healthcare, in which patients' preferences, values and context are given primacy 33 , was very clear to one general practitioner: "Many practices now have large numbers of people...doing the measurements and making sure that $Q O F$ requirements are being met...We have become so measurement-orientated, it's becoming more difficult for the patient and the doctor to have a genuine personal relationship around the patient's own circumstances" (general practitioner 5/salaried).

General practitioners are used to experiencing high degrees of uncertainty, since they regularly have to deal with an undifferentiated clinical picture 27. However, the fragmentation of roles in primary care reduces the possibility of dealing with human suffering in a multidimensional way. The QOF has the potential to reduce the doctors' role to that of achieving targets-completing computerised templates in the consultation and delegating more mechanical activities to nurses, seen by doctors as the best followers of guidelines 5 .

The QOF also favours "the fragmented thinking of the specialist which is incorporated in many protocols" rather than general practitioners' original core values 34 (p. 914). The workload division amongst sub-specialities (general practitioner with special interests), practitioner nurses and other health care staff, is supported by QOF's 'fragmentary' definition of care:

“That's happening in the hospitals... Gone is the time when you had two general cardiologists... Now you have one whose special interest is supra-extra-ventricular-tachi-arrhythmias... and someone else does the supra bradicardias or whatever. I think we are being deskilled; I don't think we could do much about it. I think it's the trend and the culture, and again, it's part of the workload. I would hope that potentially patients will get...better care, so, rather than all of us having a mediocre knowledge in diabetes...they will come to me and they will get up-to-date knowledge and up-to-date advice, but it's very difficult to be updated on absolutely everything" (general practitioner 1 /partner). 
The previous quote reflects what Hilton 35 calls the "secondary to primary care shift". This process was apparent in some other general practitioner interviews: "Things have changed over the last six or seven years and I don't think they will go back, there is more work coming in from hospitals now to us, and we have to get geared up to deal with that ...that's the current financial state of things and there is a big push to cut referrals, to cut admissions and...to save money and reconfigure the system" (general practitioner 8/partner).

Last words on this issue come from a general practitioner reporting his own difficulties in trying to get an appointment with a specific doctor: "I have a minor health problem and I rang my doctor's practice yesterday and I said 'I want to see doctor $X$ '... because I know that particular doctor... and they said 'First appointment...9th of August'. What day was yesterday? It was the 18th [of July]... so, I said 'Hah! I'd like to see him this week if it's possible'-and they said 'Well, if you ring at 8 o'clock on Friday morning he will release a few spaces for people on that day and you might get a chance to see him'...If I'd said 'I would like to see any doctor', they might have said 'OK, we can fit you in with doctor so and so, tomorrow or Wednesday or Thursday" (general practitioner 5/ salaried).

\section{Quaternary prevention}

In 2003 the World Organization of National Colleges, Academies and Academic Associations of General Practitioners/Family Physicians (WONCA) officially launched the concept of quaternary prevention: "an action taken to identify a patient at risk of over-medicalisation, to protect him [sic] from new medical invasion, and to suggest to him interventions which are ethically acceptable" 36 (p. 580). WONCA saw the concepts of holism, patient-centeredness and continuity of care as essential for putting general practitioners' biomedical knowledge into perspective. The QOF has meant patients receive a more systematic and biomedical type of care 37 , one that has the potential to medicalise "more and more aspects of human existence, human behaviour and the human body" 38 (p. 7). The QOF is also becoming a kind of health-police, for instance searching for "DNA patients" (those who "did not attend”) boosted by QOF's comprehensive information technology systems for calling and recalling patients 9 . Other practices promote "zero tolerance" of target failure in order to achieve the desired level or parameters necessary 39 . As one general practitioner graphically explains:
"The QOF came to bite like a dog biting you on your legs, on your buttocks, because what that meant was that the measurement could be done by a nurse who was paid by the practice to do the work, but the therapeutics had to be done by the doctor and the doctor had to learn the guidelines on how to treat, which drug to use, what dose, etc...in order to be able to get the desired outcomes" (general practitioner 5/salaried).

Since waiting for life-style changes in real time does not always fit with QOF timescales, the general trend is to introduce medication early on: "We have guidelines on hypertension. With QOF in the background we are more likely, maybe, to start things earlier to get them down to target.. than to wait for non-pharmacological advice... In the background you have got to get that blood pressure lower... Whereas in the old days you might give them longer non-pharmacological [time] for that and for cholesterol and some things...maybe now we are becoming more focused on 'just get on and treat'... we don't have the time necessary to get them all back" (general practitioner 8/partner).

The general practitioners always justified their changing ethos as being backed by evidence-based medicine, but there are areas where evidence is still controversial or where consensus is based on specialist opinion, which may differ from that of general practitioners':

"The year before last they brought in extra points for diabetes - Hb-1c under seven per cent, under eight per cent, under nine... They were driving us to get patients' $\mathrm{Hb}$-1c lower. At the same time, the last two or three years there have seen studies suggesting... they don't want to be too low... [it] could be dangerous to get the Hb-1c too low... 7.5 is a better target to have, whereas for QOF I'm being told or being paid to get people under seven per cent and, at the same time, the evidence is changing" (general practitioner 1/partner).

Medicalisation of pre-disease states and risk factors (lowering targets for cholesterol, Hb-1c and blood pressure) has become increasingly common, raising concern about over-medicalisation 36. The following general practitioner characterised the effect of QOF on general practice over time as being due to changes in the disease concept whereby what was once a risk factor has now become almost synonymous with disease 36 .

"In the past people came to see us if they felt something was wrong... Now, probably half... are here because of something we have identified as wrong... because we have detected their high blood pressure or their abnormal blood glucose. It must be... frustrating for patients who can't get appointments when they are sick because these appointments have been taken up by people who 
are well, or who are being followed up because of biochemical... [or] physiological abnormalities" (general practitioner 13/partner).

The approach to reduce disease-specific risk factors is consonant with the idea of "susceptibility", which brings the potential future into the present, making patients subjects of calculation and objects of remedial intervention 40 .

This trend of pre-patients will spread as more and more threats to health are created 40 . This has the potential both to reduce quality of life (by labelling healthy people as "sick') and to increase health service and medication use ${ }^{41}$. In 2004, QOF has increased the UK's national medicine bill by between $3 \%$ and $5 \%$, since a quarter of agreed target points depend on the use of appropriate medication 42 .

In 2006, QOF introduced some controversial new targets, such as those for kidney disease and depression. One general practitioner commented on the "real problem" the latter posed for her practice: "I don't find that they are appropriate to use... I find it intrusive and not good for patient care to ask them to fill in the form there and then, and there is no evidence to say that this is actually good practice... We put a code on the computer to say 'low mood' until we get the PHQ-9 score back and, it might be a stress-related work problem or issue but, as soon as you've done the PHQ... all of a sudden... some of these label them as having low, moderate or high... which has implications for the patients from an insurance point of view, from their work point of view, occupational health and, medico-legally, for us" (general practitioner $7 /$ partner)

These contradictory situations - where "scientific" evidence-based targets are not aligned with the inner values of physicians - show how powerful money has been in changing doctors' behaviour. Despite doctors regarding some targets as "inappropriate", they strive to achieve them, adapting their practices to get the 'points' required to get paid 43 . Thus, QOF provides a systematic and powerful system for delivering any intervention sanctioned by the institutions evaluating "scientific" evidence.

\section{Discussion}

This study has presented the views of a selection of general practitioners working in the UK about the effects of QOF on their principles and practice: holism, doctor-patient relationships, continuity of care and quaternary prevention. This sample profile does not necessarily reflect more general attitudinal and behavioural patterns. However, practices in the UK generally achieve high scores in their QOF targets, suggesting a high level of consistency in their approach to them. Moreover, being the principal researcher a Brazilian general practitioner might have had fuller and more candid interview discussions about QOF than would have occurred with a non-clinical researcher. Further interviews might have yielded fresh insights, but the themes identified were so consistent it is unlikely any substantially new knowledge would have been generated.

Hence, according to our findings, it seems that under the rhetoric of holism and patient centeredness 25, the 2004 General Medical Service contract is pushing the biomedical model further into community-based practice than ever before, limiting the potential for general practitioners' autonomy, critical application of evidence-based medicine and reflective practice ${ }^{9}$. Although Sackett et al. 44 did not frame evidence-based medicine as a "slavish, cookbook approach" to clinical practice, experience has proved otherwise. Thus, QOF has become an audit and managerial instrument controlling doctors' autonomy by paying them to "conform" to the prescribed clinical protocols ${ }^{9}$. In this framework, money has proved to be a strong driver, even against doctors' wills, exemplified in the case of depression and chronic kidney disease indicators/targets 43 . The QOF's “currency” has prompted doctors to divert their attention toward getting their "points" and generating income 45 , leading to a conceptual commodification in the UK health sector 26 . This is aligned with general trends towards privatisation of the NHS and "a weakening of its public service ethos" 46.

This finds common ground with current debates on QOF 6, as researchers 17,19 suggest that this new managerial culture, may has strengthened a scientific-bureaucratic model of medicine amongst primary care practitioners in the UK. There are concerns that primary care in the UK has been gradually transformed into a "box ticking" activity: a kind of "McDonaldization" of general practice 47 . Researchers 9,39,43 have also stated that UK general practices deliver an increasingly fragmentary, reductionist and biomedical, disease-oriented model of care. Hence, it can be argued, that far from becoming a "locus of social revolution” 48 contemporary UK primary healthcare appears to be becoming a monocultural and increasingly standardised environment. Thus, QOF represents the apogee of a cultural shift towards more biomedically-based principles and practice amongst general practitioners in the UK.

Moreover, a recent systematic review on QOF shows modest benefits in improving the quality of primary care and alerts policy makers 
that "the impact on costs, professional behaviour, and patient experience remains uncertain" 49 (p. 461). This resonate with the Cochrane review on healthcare quality provided by primary care physicians under the payment for performance scheme 50 . Thus, it seems that $£ 1$ bn $(€ 1.2 \mathrm{bn}$; $\$ 1.4 \mathrm{bn}$ ) a year "is not good value for money" for UK general practices, since quality in health in the UK would reach nearly the same level of standards according to the "secular trends" before QOF was introduced 6,51.

Regarding current evidence on payment for performance from both qualitative and quantitative studies, it leaves policy makers with more doubts than certainties 6 . Furthermore, for low and middle-income countries such as Brazil, there is a lack of good evidence for implementing this management style in public health systems. Nevertheless, it is necessary to find alternative ways for awarding quality in Brazil's primary healthcare and the work being carried out by its professional staff. In 2011 in Brazil, the Brazilian Health Ministry launched the National Programme for Improving Access and Quality in Primary Care (PMAQ-AB) 52 in order to strengthen Brazil's primary health care. The aim is to improve health services through financial incentives based on agreed quality goals with family health teams. For example, in the PMAQ-AB quality financial incentives are variable and dependent on the results achieved by family health teams and the municipalities' administration. These incentives will be transferred monthly, based on the number of teams registered in the programme and criteria defined by PMAQ's specific rules 52 . At the grassroots of PMAQ-AB "are commitments and indicators to be agreed amongst family health teams, city health managers and the Ministry of Health" 52 (p. 10).
Moreover, as the Brazilian Unified National Health System (SUS) allows almost autonomous discretionary spaces at municipality level 53 , the payment for performance is being introduced 54 by local initiatives without formal evaluative plans for weighting its harms and benefits. An example is the municipality of Rio de Janeiro which introduced payment for performance based on the Portuguese model, which in turn was based on the British payment for performance scheme 55. However, in light of the current evidence, local policy makers when using the payment for performance concept should be careful and target broader quality indicators 6 (or health concepts) 36 for primary care such as rapid access and time working in the same family health team (continuity) - rather than focusing on biomedical markers such as cholesterol, blood pressure and the like - which may reduce some of its unintended consequences by reconciling them with values inherent to family medicine.

\section{Conclusion}

This study complements and expands upon a small body of qualitative research on the effects of QOF on general practice in the UK. Therefore, it contributes towards understanding its effects, since QOF was launched "without a comparison group and no planned evaluation", leaving researchers interested in its benefits and harms to rely on observational studies (of which this is an example) and those that use existing datasets 6,56. In summary, this study suggests that QOF has had profound effects on the way family medicine is practiced in the UK. 


\section{Resumen}

Este artículo explora algunos efectos del modelo británico de pago por desempeño en los principios y práctica de médicos generales que pueden contribuir a cuestiones relacionadas con modalidades de incentivos financieros y calidad de servicios de atención primaria en países de bajos y medios ingresos. La investigación tuvo por objetivo lo que los médicos tienden a decir sobre el efecto del pago por desempeño británico en su ethos profesional; se realizaron entrevistas semi-estructuradas con 13 médicos generales, educadores y líderes en medicina académica del Reino Unido. Los resultados muestran cambios hacia un modelo de práctica más biomédica y atención fragmentada con enfermeras y otros profesionales enfocados en enfermedades específicas. También produjo un aumento en medicalización de la experiencia del paciente a través de rotulaciones $y$ tendencia a prescribir medicamentos en lugar de intervenciones no farmacológicas. Así, el pago por desempeño británico ha reforzado gradualmente un modelo científico-burocrático de práctica que ha tenido profundos efectos en la forma en la que la medicina familiar está siendo practicada en el Reino Unido.

Medicina Familiar y Comunitaria; Remuneración; Medicina General

\section{Contributors}

A. H. Norman participou da concepção, análise e in terpretação de dados e redação do artigo. A. J. Russell contribuiu na revisão crítica relevante do conteúdo intelectual e redação do artigo. J. Macnaughton colaborou na revisão crítica e redação do artigo.

\section{Acknowledgments}

The authors would like to thank the 13 general practitioners who gave of their time so freely to share with us their experiences of and reflections on the QOF. We also wish to thank Sudeh Cheraghi-Sohi, PhD., who kindly helped the main researcher in understanding some of the peculiarities of the GMS contract. Finally, our thanks to Professor Charles Tesser for his insightful comments on our paper and to Santander Scholarship for their financial support.

\section{References}

1. Gérvas J, Pérez-Fernández M. Pago por desempeño ("pay for performance") [P4P]. Actualización en Medicina de Familia 2008; 4:344-52.

2. Robinson JC. Theory and practice in the design of physician payment incentives. Milbank Q 2001; 79:149-77.

3. Pieró S, García-Altés A. Posibilidades y limitaciones de la gestión por resultados de salud, el pago por objetivos y el redireccionamiento de los incentivos. Gac Sanit 2008; 22 Suppl 1:143-55.

4. Cheraghi-Sohi S. Contractual change and UK general practitioners: still a case of street-level bureaucrats? [PhD Thesis]. Manchester: Faculty of Medicine and Human Sciences. Manchester University School; 2011.
5. McDonald R, Harrison S, Checkland K, Campbell SM, Roland M. Impact of financial incentives on clinical autonomy and internal motivation in primary care: ethnographic study. BMJ 2007; 334:1357.

6. Gillam S, Steel N. The Quality and Outcomes Framework - where next? BMJ 2013; 346:f659.

7. Simon C. Overview of the GP contract. InnovAiT 2008; 1:134-9.

8. Gillam S, Siriwardena N. Introduction: development, impact and implications. In: Gillam S, Siriwardena N, editors. The Quality and Outcomes Framework: QOF-transforming general practice. Oxford: Radcliffe Publishing; 2011. p. 3-7. 
9. Checkland K, Grant S, Harrison S, Grant S, Campbell S, Guthrie B. Biomedicine, holism and general medical practice: responses to the 2004 general practitioner contract. Sociol Health Illn 2008; 30:788-803.

10. Cole A. UK GP activity exceeds expectations. BM] 2005; 331:536.

11. Raffle AE, Gray JAM. Screening evidence and practice. Oxford: Oxford University Press; 2007.

12. Donabedian A. Evaluating the quality of medical care (1966). Milbank Q 2005; 83:691-729.

13. Roland M. Where did the Quality and Outcomes Framework come from? In: Gillam S, Siriwardena N, editors. The Quality and Outcomes Framework: QOF-transforming general practice. Oxford: Radcliffe Publishing; 2011. p. 8-15.

14. Pollitt CJ. Managerialism and the public services. 2nd Ed. Oxford: Blackwell; 1993.

15. Power M. The audit society: rituals of verification. Oxford: Oxford University Press; 1997.

16. Power M. Evaluating the audit explosion. Law Policy 2003; 25:185-202.

17. Harrison S. New labour, modernisation and the medical labour process. J Soc Policy 2002; 31: 465-85.

18. National Health Service Executive. A first class service: quality in the new NHS. London: Department of Health, National Health Service; 1998.

19. Harrison S, Moran M, Wood B. Policy emergence and policy convergence: the case of "scientific-bureaucratic medicine" in the United States and United Kingdom. The British Journal of Politics and International Relations 2002; 4:1-24.

20. Lambert $\mathrm{H}$. Accounting for EBM: notions of evidence in medicine. Soc Sci Med 2006; 62:2633-45.

21. Helman C. The culture of general practice. Br J Gen Pract 2002; 52:619-20.

22. Campbell S, Hannon K, Lester H. Exception reporting in the Quality and Outcomes Framework: views of practice staff - a qualitative study. $\mathrm{Br} \mathrm{J}$ Gen Pract 2011; 61:183-9.

23. Lester H, Campbell S. Developing Quality and Outcomes Framework (QOF) indicators and the concept of "QOFability”. Qual Prim Care 2010; 18:103-10.

24. Wilkie P. Does patient always benefit? In: Gillam S, Siriwardena A, editors. The Quality and Outcomes Framework: QOF-transforming general practice. Oxford: Radcliffe Publishing; 2011. p. 128-36.

25. Royal College of General Practitioners. Curriculum statement 1: being a general practitioner. http:// www.rcgpcurriculum.org.uk/PDF/curr_1_Curricu lum_Statement_Being_a_GP.pdf (accessed on 30/ Aug/2011).

26. Harrison S. Co-optation, commodification and the medical model: governing UK medicine since 1991. Public Adm 2009; 87:184-97.

27. McWhinney IR. William Pickles Lecture 1996. The importance of being different. Br J Gen Pract 1996; 46:433-6.
28. Lambert H, Gordon EJ, Bogdan-Lovis E. Introduction: gift horse or Trojan horse? Social science perspectives on evidence-based health care. Soc Sci Med 2006; 62:2613-20.

29. Freeman G, Hjortdahl P. What future for continuity of care in general practice? BMJ 1997; 314:1870-3.

30. Hjortdahl P, Laerum E. Continuity of care in general practice: effect on patient satisfaction. BMJ 1992; 304:1287-90.

31. Rosser WW, Shafir MS. Evidence-based family medicine. Hamilton: B.C. Decker Inc.; 1998.

32. Campbell SM, Reeves D, Kontopantelis E, Sibbald B, Roland M. Effects of pay for performance on the quality of primary care in England. New Engl J Med 2009; 361:368-78.

33. Haggerty JL, Reid RJ, Freeman GK, Starfield BH, Adair CE, McKendry R. Continuity of care: a multidisciplinary review. BMJ 2003; 327:1219-21.

34. Gérvas J, Starfield B, Violán C, Minué S. GPs with special interests: unanswered questions. Br J Gen Pract 2007; 57:912-7.

35. Hilton S. Education and the changing face of medical professionalism: from priest to mountain guide? Br J Gen Pract 2008; 58:353-61.

36. Starfield B, Hyde J, Gérvas J, Heath I. The concept of prevention: a good idea gone astray? J Epidemiol Community Health 2008; 62:580-3.

37. Checkland K, Harrison S. The impact of the Quality and Outcomes Framework on practice organisation and service delivery: summary of evidence from two qualitative studies. Qual Prim Care 2010; 18:139-47.

38. Samuelsen H, Steffen V. The relevance of Foucault and Bourdieu for medical anthropology: exploring new sites. Anthropol Med 2004; 11:3-10.

39. McDonald R, Harrison S, Checkland K. Incentives and control in primary health care: findings from English pay-for-performance case studies. J Health Organ Manag 2008; 22:48-62.

40. Rose N. The politics of life itself: biomedicine, power, and subjectivity in the twenty-first century. Princeton: Princeton University Press; 2006.

41. Montori V, Isley W, Guyatt G. Waking up from the DREAM of preventing diabetes with drugs. BMJ 2007; 334:882-4.

42. Mangin D, Toop L. The Quality and Outcomes Framework: what have you done to yourselves? $\mathrm{Br}$ J Gen Pract 2007; 57:435-37.

43. Campbell S, Lester H. The experience of pay for performance in English family practice: a qualitative study. Ann Fam Med 2008; 6:228-34.

44. Sackett D, Rosenberg WMC, Gray JAM, Haynes RB, Richardson WS. Evidence based medicine: what it is and what it isn't. BMJ 1996; 312:71-2.

45. Heath I, Hippisley-Cox J, Smeeth L. Measuring performance and missing the point? BMJ 2007; 335:1075-6.

46. Hunter DJ. Change of government: one more big bang health care reform in England's National Health Service. Int J Health Serv 2011; 41:159-74. 
47. Gillam SJ, Siriwardena N. The quality and outcomes framework: triumph of technical rationality, challenge for individual care? Qual Prim Care 2010; 18:81-3.

48. Scheper-Hughes N. Three propositions for a critically applied medical anthropology. Soc Sci Med 1990; 30:189-97.

49. Gillam SJ, Siriwardena N, Steel N. "Pay-for-performance in the United Kingdom": impact of the Quality and Outcomes Framework - a systematic review. Ann Fam Med 2012; 10:461-8.

50. Scott A, Sivey P, Ait Ouakrim D, Willenberg L, Naccarella L, Furler J, et al. The effect of financial incentives on the quality of health care provided by primary care physicians. Cochrane Database Syst Rev 2011; (9):CD008451.

51. Gillam S. Should the quality and outcomes framework be abolished? Yes. BMJ 2010; 340:c2710.

52. Departamento de Atenção Básica, Secretaria de Atenção à Saúde, Ministério da Saúde. Programa Nacional de Melhoria do Acesso e da Qualidade da Atenção Básica (PMAQ): manual instrutivo. http:// www.saude.mt.gov.br/arquivo/3183 (accessed on 24/Jan/2012).
53. Atkinson S. Political cultures, health systems and health policy. Soc Sci Med 2002; 55:113-24.

54. Faria RIN. Pay-for-performance in Brazil: an analysis of case studies [Masters Thesis]. York: University of York; 2010.

55. Secretaria Municipal de Saúde e Defesa Civil. Anexo técnico B do contrato de gestão: acompanhamento, avaliação e metas para os serviços de saúde - área de planejamento. http://subpav.org/ download/prot/Pagamento_por_performance_ versao_FINAL.pdf (accessed on 06/Sep/2012).

56. Steel N, Willems S. Research learning from the UK Quality and Outcomes Framework: a review of existing, Qual Prim Care 2010; 18:117-26.

Submitted on 19/Oct/2012

Final version resubmitted on 30/Jun/2012

Approved on 18/Jul/2013 